\title{
Somatostatin, an Inhibitor of ACTH Secretion, Decreases Cytosolic Free Calcium and Voltage-Dependent Calcium Current in a Pituitary Cell Line
}

\author{
Alberto Luini, ${ }^{\star}$ Deborah Lewis, $\uparrow$ Simon Guild, $\$$ Geoffrey Schofield, $\uparrow$ and Forrest Weight $\dagger$ \\ *Laboratory of Cell Biology, National Institute of Mental Health, National Institutes of Health, Bethesda, Maryland \\ 20892, †Laboratory of Preclinical Studies, National Institute on Alcohol Abuse and Alcoholism, Rockville, \\ Maryland 20852, and łExperimental Therapeutics Branch, National Institute on Neurological, Communicative \\ Disorders and Stroke, National Institutes of Health, Bethesda, Maryland 20892
}

\begin{abstract}
Somatostatin is a neurohormone peptide that inhibits a variety of secretory responses in different cell types. We have investigated the effects of somatostatin on calcium current and intracellular free calcium in AtT-20 cells, a pituitary tumor line in which the inhibitory actions of this peptide have been well characterized. At concentrations similar to those that inhibit adrenocorticotropic hormone (ACTH) release, somatostatin and its analogs reduced the levels of intracellular free calcium (as measured by the Quin-2 technique). Nifedipine and other blockers of voltage-dependent calcium channels also reduced cytosolic calcium levels. The effects of somatostatin and nifedipine were not additive, suggesting that somatostatin might inhibit calcium channels. Experiments using the whole-cell patch-clamp technique showed that somatostatin reduces voltage-dependent calcium current. The effects of somatostatin on cytosolic calcium and calcium current appear to be independent of its ability to reduce secretagogue-stimulated CAMP accumulation in these cells. We propose that the somatostatin-induced decrease in cytosolic calcium concentrations and the voltage-dependent calcium current are one of the mechanisms by which somatostatin suppresses ACTH release in AtT-20 cells.
\end{abstract}

The tetradecapeptide somatostatin is widely distributed in the brain and peripheral organs (Reichlin, 1984). Many of the known physiological effects of somatostatin are due to its inhibitory activity on the secretory response of a variety of both pituitary (Axelrod and Reisine, 1984; Vale et al., 1977) and extrapituitary cells (Boden et al., 1975; Fujimoto et al., 1974; Pace and Tarvin, 1981). Because of the central role of calcium in secretion, it has been proposed that the secretion-inhibiting action of somatostatin may be due to its effects on calcium movement in target cells (Maruyama and Ishikawa, 1977; Oliver, 1976; Richardson, 1983; Schlegel et al., 1984; Schofield and Bicknell, 1978). The precise nature of these effects is, however, not completely understood. We have studied the mechanism of action of somatostatin in At T-20 cells, a mouse pituitary tumor cell line in which the effects of this peptide have been well characterized (Axelrod and Reisine, 1984).

AtT-20 cells secrete adrenocorticotropic hormone (ACTH) in response both to secretagogues that stimulate cAMP synthesis

\footnotetext{
Received Dec. 9, 1985; revised Apr. 14, 1986; accepted May 6, 1986.

We are grateful to Julius Axelrod for fruitful discussions and advice. We thank Mary Flanagan-Cyr for expertly preparing the typescript.

Correspondence should be addressed to Alberto Luini, M.D., Mario Negri Institute, Via Eretrea 62, Milan, Italy 20157.

$0270-6474 / 86 / 113128-05 \$ 02.00 / 0$
}

(corticotropin releasing factor, vasointestinal peptide, isoproterenol, and forskolin) and to secretagogues independent of cAMP formation, such as potassium, 8-bromocyclic AMP, calcium ionophores (Axelrod and Reisine, 1984) and phorbol esters (Heisler, 1984). Somatostatin blocks the stimulation of secretion by all of these agents (Axelrod and Reisine, 1984; Richardson, 1983). A previously described mechanism of action of somatostatin is the blockade of the secretagogue-evoked stimulation of cAMP synthesis (Heisler et al., 1982). We now report a novel effect of somatostatin; namely, the inhibition of voltage-dependent calcium channels and the decrease of basal cytosolic calcium levels. We propose that this effect, which is independent of cellular cAMP concentrations, could be an important component of the release-inhibiting activity of somatostatin.

\section{Materials and Methods}

\section{Preparation of cell cultures}

AtT-20/D16-16 cells were subcultured and grown as monolayers in culture flasks or in petri dishes as previously described (Hook et al., 1982). Cells were detached from flasks by gently flushing them with Dulbecco's modified Eagle's medium (DMEM) containing 10\% fetal calf serum (growth medium). The cells $\left(10^{5} / \mathrm{ml}\right)$ were then incubated in plastic petri dishes at $37^{\circ} \mathrm{C}$ in a humidified atmosphere of $10 \% \mathrm{CO}_{2}$ in air. Under these conditions, they remained viable (by the trypan blue exclusion test) and responsive to somatostatin for up to $2 \mathrm{hr}$. Secretion of ACTH in response to secretagogues was also maintained.

\section{Quin-2 fluorescence}

Cytosolic calcium was measured using the fluorescent calcium probe Quin-2 (Tsien et al., 1982). For Quin-2 loading, the cells from one petri dish $\left(5 \times 10^{6}\right)$ were washed twice with DMEM containing $1 \mathrm{mg} / \mathrm{ml} \mathrm{BSA}$ and resuspended in $10 \mathrm{ml}$ of the same medium. A $50 \mu \mathrm{l}$ aliquot of 10 mM Quin-2 acetoxymethylester in dimethylsulfoxide was added to the cell suspension and incubated with gentle agitation at $37^{\circ} \mathrm{C}$ for $15 \mathrm{~min}$. The cells were then washed twice in DMEM/BSA and resuspended in growth medium at the density of $2 \times 10^{6} \mathrm{cells} / \mathrm{ml}$. Aliquots of $1 \mathrm{ml}$ were placed in plastic tubes and kept in a humidified atmosphere of 5\% $\mathrm{CO}_{2}$ in air at $37^{\circ} \mathrm{C}$. For fluorescence determinations, one aliquot was added to $14 \mathrm{ml}$ of Hank's medium containing $0.2 \mathrm{mg} / \mathrm{ml} \mathrm{BSA}$, centrifuged, and resuspended in $2 \mathrm{ml}$ of the same medium. The cell suspension was then placed in a quartz cuvette in a temperature-controlled $\left(37^{\circ} \mathrm{C}\right)$ Perkin-Elmer spectrophotofluorometer (model 3000), where they were gently stirred with a magnetic stirrer. Cytosolic calcium concentrations were calculated by the calibration procedure of Tsien et al. (1982). The Quin-2 fluorescence trace was very steady in unstimulated cells. This allowed detection of changes in cytosolic calcium as small as $7 \%$ of the basal values in individual samples. Preparations where the fluorescence signal drifted slowly upward, indicating loss of cell viability, were discarded. 


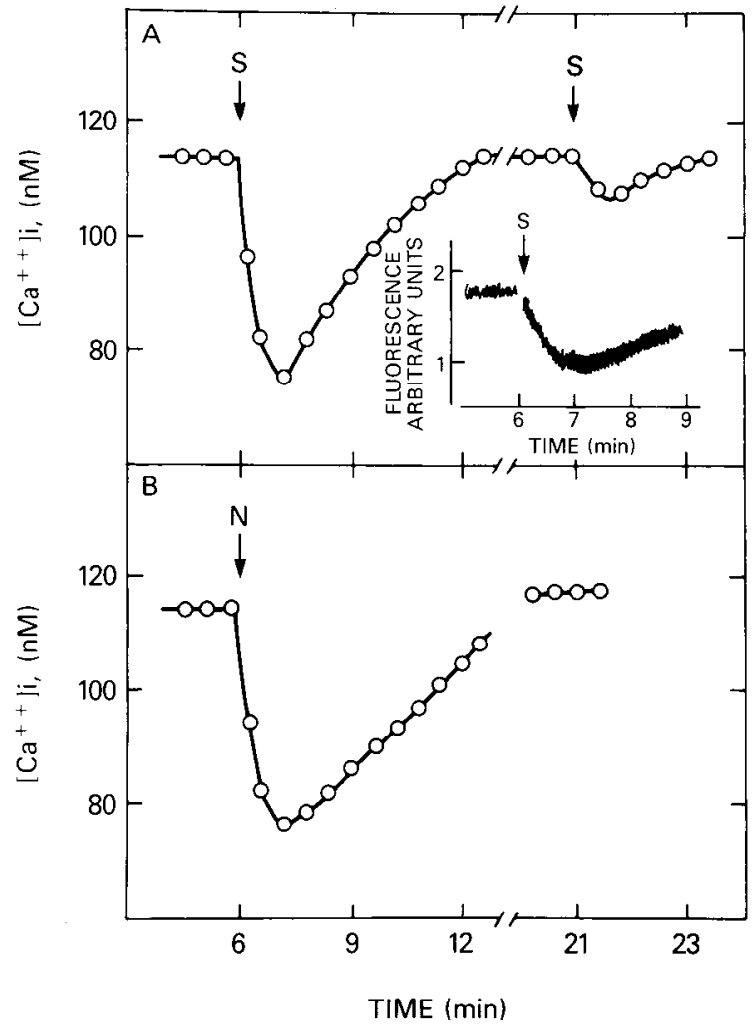

Figure 1. Decrease in cytosolic calcium caused by somatostatin and nifedipine. $A$, Effect of 2 successive additions of $10^{-7} \mathrm{M}$ somatostatin $(S)$. A representative Quin-2 fluorescence trace is shown in the inset. Traces were stable and sensitive to the the first addition of somatostatin for at least $25 \mathrm{~min}$. $B$, Effect of $10^{-6} \mathrm{M}$ nifedipine $(N)$. Nisoldipine $\left(10^{-7}\right.$ $\mathrm{M})$ and verapamil $\left(10^{-5} \mathrm{M}\right)$ produced a decrease in cytosolic calcium similar to that caused by $10^{-6} \mathrm{M}$ nifedipine (not shown). Valucs arc means of 4-6 experiments carried out using 4 different cell preparations. SDs were less than $10 \%$ of the means.

\section{Whole-cell patch-clamp}

The patch-clamp method was used to record the calcium current in the whole-cell voltage-clamp mode (Hamill et al., 1981). Currents were recorded in an external solution containing (in mM): 150 TEA-Cl, 0.8 $\mathrm{MgCl}_{2}, 5.4 \mathrm{KCl}, 10 \mathrm{CaCl}_{2}, 10$ HEPES (pH 7.4), 45 glucose, $10^{-6} \mathrm{M}$ TTX, and $1 \mathrm{mg} / \mathrm{ml} \mathrm{BSA}$, with an osmolarity of $340 \mathrm{mOsm} \mathrm{kg} \mathrm{g}^{-1}$. The solution in the patch pipette (internal) contained (in mM): $120 \mathrm{CsCl}, 11 \mathrm{EGTA}$, 2 TEA-Cl, $2 \mathrm{MgCl}_{2}, 10$ HEPES (pH 7.4), 4 MgATP, 20 creatine phosphate, and 50 units $/ \mathrm{ml}$ creatine kinase, with an osmolarity of $318 \mathrm{mOsm}$ $\mathrm{kg}^{-1}$. Currents were filtered using a $3 \mathrm{kHz}$ low-pass Bessel filter, digitized at $250 \mu \mathrm{sec} /$ point, and stored for analysis using a PDP-11/23 microcomputer. The linear leak component, measured between -120 and $-60 \mathrm{mV}$, was digitally substracted from the $I-V$ plots. Cell input resistance, measured between -120 and $-60 \mathrm{mV}$, was $2.0-7.9 \mathrm{G} \Omega$. All recordings were made at room temperature $\left(22-25^{\circ} \mathrm{C}\right)$. Somatostatin was dissolved in the external solution at the concentrations stated and applied via a macropipette placed near the surface of the cell under study. The application of somatostatin was terminated by withdrawal of the somatostatin-containing macropipette.

\section{Materials}

Synthetic somatostatin (1-14) and [D-Trp ${ }^{8}$-somatostatin were obtained from Bachem (Torrance, CA). BSA, dimethylsulfoxide, nifedipine, verapamil, tetraethylammonium (TEA) chloride, adenosine $3^{\prime}, 5^{\prime}$-cyclic monophosphate (cAMP), 3-isobutyl-1-methyl-xanthine (IBMX), and 8-bromocyclic AMP were from Sigma (St. Louis, MO). Quin-2 tetracetoxymethylester (Quin-2 AM) and Quin-2 were purchased from Calbiochem-Behring (La Jolla, CA). Nisoldipine was a gift from Dr. P.

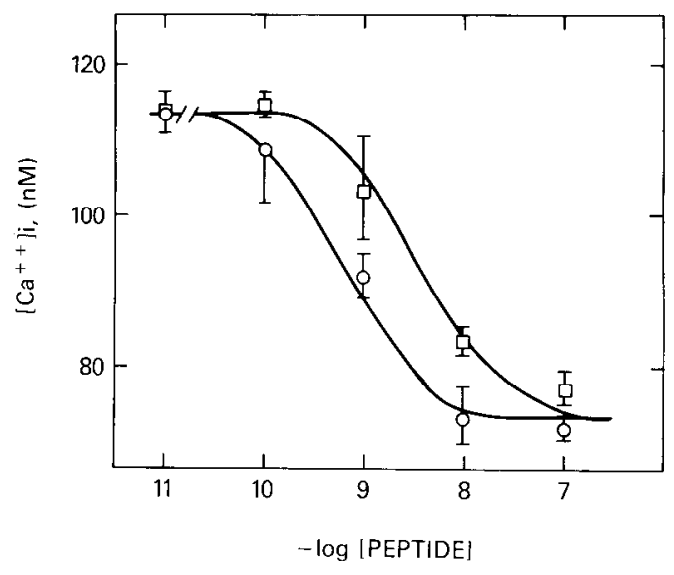

Figure 2. Concentration dependence of the effects of somatostatin and [D-Trp ${ }^{8}$ ]-somatostatin on cytosolic calcium concentrations. The cytosolic concentrations of calcium at the time at which somatostatin (squares) and [D-Trp ${ }^{8}$-somatostatin (circles) produced their maximal effect (approximately $90 \mathrm{sec}$ after application) are shown graphically as a function of the concentration of the peptides. Values are means from 4-6 experiments, carried out using 6 different cell preparations.

Marangos. DMEM was from Gibco (Grand Island, NY), and fetal calf serum was purchased from M. A. Bioproducts (Walkersville, MA) and KC Biological Laboratories (Lenexa, KS).

\section{Results and Discussion}

\section{Cytosolic calcium}

Cytosolic calcium was measured using the fluorescent calcium probe Quin-2. The addition of somatostatin or its analog [ $\mathrm{D}$ Trp 8 -somatostatin decreased the basal cytosolic free calcium levels of AtT-20 cells (Fig. $1 A$ ) in a dose-dependent manner (Fig. 2). The concentrations of somatostatin that reduced cytosolic calcium were similar to those reported by Heisler et al. (1982) but higher than those reported by Reisine $(1984,1985)$ to inhibit the secretagogue-induced release of ACTH. [D-Trp ${ }^{8}$ ]somatostatin was slightly more potent than somatostatin-14 in reducing cytosolic calcium. A similar difference in analog potency with regard to ACTH release was previously reported (Reisine, 1984), although not consistently (Reisine, 1985). It is not clear whether these differences in somatostatin potency in different studies are due to changes in the sensitivity of the cells to somatostatin or to variations in the purity and effectiveness of different batches of the peptide.

We tested whether the effect of somatostatin on cytosolic calcium might be due to a reduced calcium influx using agents that inhibit calcium influx. Blockers of voltage-dependent calcium channels such as nifedipine $\left(\mathrm{EC}_{50}=2 \times 10^{-8} \mathrm{M}\right)$, nisoldipine, and verapamil, which inhibit stimulated ACTH secretion (Axelrod and Reisine, 1984), also decreased cytosolic calcium (Fig. $1 B$ ). Since AtT-20 cells exhibit spontaneous action potentials (Adler et al., 1983; Surprenant, 1982), the decrease in cytosolic calcium caused by these agents could be due to a reduced influx of calcium through voltage-dependent calcium channels. The maximal effect of nifedipine was similar to that elicited by somatostatin (Fig. 1B). Furthermore, when nifedipine was applied at the peak of somatostatin action, or when somatostatin was applied at the peak of nifedipine action, no further decrease in free calcium could be detected. The lack of additivity between the 2 compounds may be due to calcium homeostatic mechanisms preventing an excessive lowering of the levels of cytosolic calcium. It is also possible that these compounds may have a common mechanism of action and that somatostatin may de- 
A

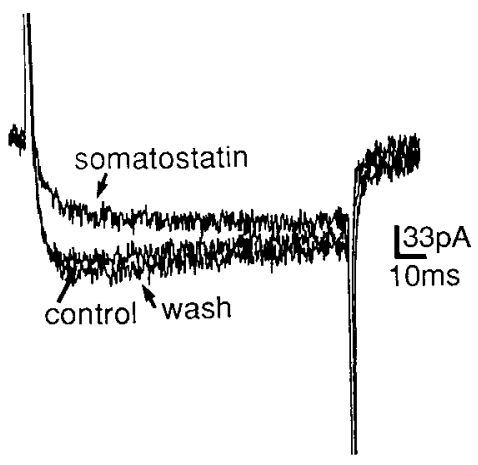

C
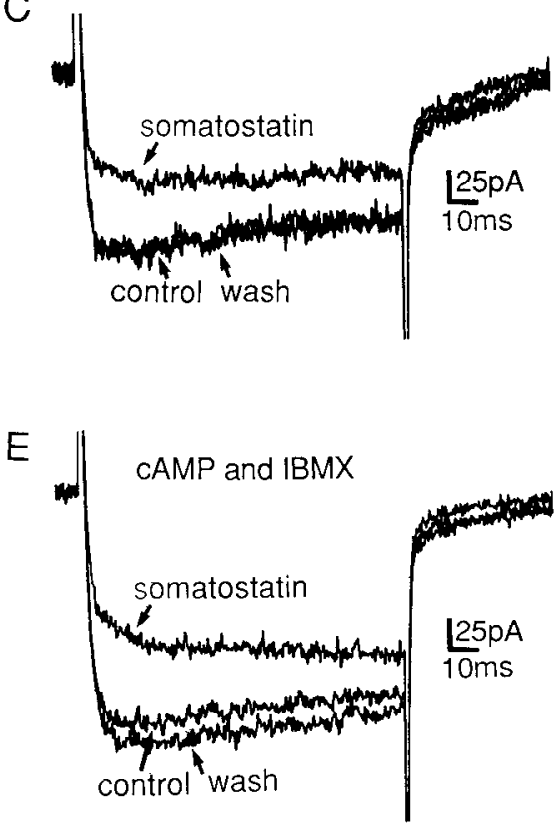

B

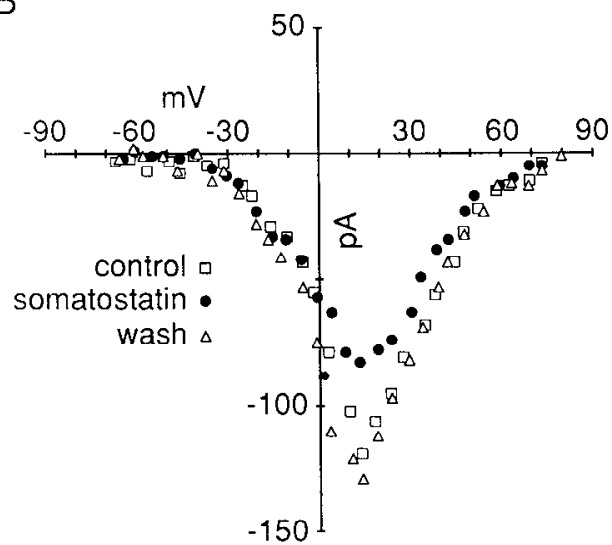

D
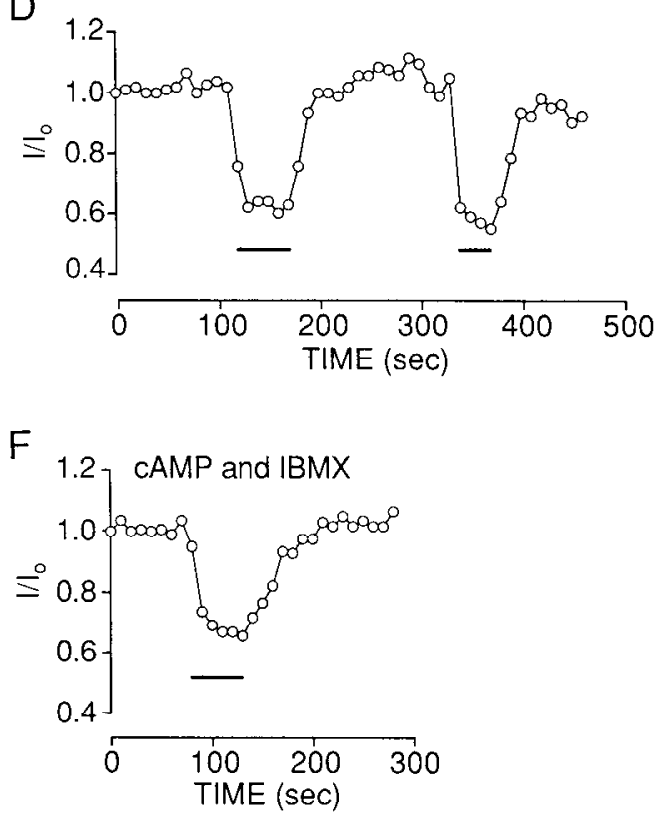

Figure 3. Effect of somatostatin on the voltage-dependent calcium current. $A$, Current records of the calcium current elicited by stepping from a holding potential of $-80 \mathrm{mV}$ to command potential of $+16 \mathrm{mV}$ prior to somatostatin application (control), 2 min after somatostatin (10 ${ }^{-8} \mathrm{M}$ ) application (somatostatin), and $2 \mathrm{~min}$ after withdrawal of the somatostatin macropipette (wash). B, Current-voltage (I-V) curve obtained by measuring the current isochronally $15 \mathrm{msec}$ after the voltage step from a holding potential of $80 \mathrm{mV}$ to the test potentials for control (squares), $10^{-8} \mathrm{M}$ somatostatin-14 (closed circles), and wash ( $2 \mathrm{~min}$ after withdrawal of the somatostatin macropipette; triangles). $C$, Current records for the experiment shown in $D$ for the calcium current $10 \mathrm{sec}$ before somatostatin application (control), 30 sec after the first application of [D-Trp ${ }^{8}$ somatostatin (somatostatin), and $60 \mathrm{sec}$ after withdrawal of the somatostatin macropipette (wash). $D$, Time course of the effect of somatostatin on the calcium current. The calcium current was elicited every $10 \mathrm{sec}$ by a step from a holding potential of $-80 \mathrm{mV}$ to a command potential of +10 $\mathrm{mV}$. The current is expressed as a ratio between the current at each time point $(I)$ and the current at time $0\left(I_{0}\right)$. Measurements were begun after the current amplitude had stabilized (time 0$)$. [D-Trp 8 ]-somatostatin $\left(10^{-6} \mathrm{M}\right.$ ) was applied twice via the macropipette (horizontal bars) and reduced the current by $38.7 \%$ during the first $60 \mathrm{sec}$ application and by $43.8 \%$ during the second $40 \mathrm{sec}$ application. $E$, Current records for the experiment shown in $F$ for the effect of somatostatin on the calcium current when the cell was internally perfused with $100 \mu \mathrm{M}$ cAMP and $1 \mathrm{mM}$ IBMX in the patch pipette. Currents shown are $10 \mathrm{sec}$ before [D-Trp $]$-somatostatin $\left(10^{-7} \mathrm{M}\right)$ application (control), 30 sec after [D-Trp ${ }^{8}$-somatostatin application (somatostatin), and $60 \mathrm{sec}$ after the somatostatin macropipette was withdrawn (wash). F. Time course of the effect of [D-Trp $\left.{ }^{8}\right]$-somatostatin on the calcium current amplitude in the presence of intracellular cAMP $(100 \mu \mathrm{M})$ and IBMX $(1 \mathrm{mM})$. [D-Trp]-somatostatin $\left(10^{-7} \mathrm{M}\right)$ reduced the calcium current amplitude by $33 \%$ during a $60 \mathrm{sec}$ application. Current records in $A, C$, and $E$ are not leak subtracted.

crease cytosolic calcium by inhibiting voltage-dependent calcium channels.

\section{Calcium current}

The whole-cell patch-clamp technique (Hamill et al., 1981) was employed to examine directly whether somatostatin affects a membrane calcium current. Ion substitution and pharmacologic agents in the external and patch-pipette (internal) solutions were used to inhibit sodium and potassium currents. The cells were voltage-clamped to a holding potential of $-80 \mathrm{mV}$, and steps to various test potentials were applied. Steps to potentials more positive than $-40 \mathrm{mV}$ elicited an inward current that decayed slowly (Fig. 3, $A, C, E$ ). The amplitude of the inward current increased with more positive step potentials until it reached a maximum at approximately $+10 \mathrm{mV}$ (Fig. $3 B$ ). The inward current was eliminated by $10 \mathrm{~mm}$ external cobalt, re- 
duced by low external calcium ( $0.1 \mathrm{~mm})$, and barium substituted as a charge carrier for calcium (not shown), indicating that the current was carried by calcium ions.

Somatostatin applied extracellularly from a macropipette in concentrations from $10^{-8}$ to $10^{-6} \mathrm{M}$ reduced the inward voltagedependent calcium current (Fig. 3). Somatostatin in low concentrations $\left(10^{-10} \mathrm{M}\right)$ and vehicle applied via the macropipette had no apparent effect on the calcium current (not shown). Figure $3 B$ illustrates the current-voltage $(I-V)$ relationship for the effect of somatostatin on the calcium current. The peak of the $I-V$ curve was reduced an average of $30.2 \pm 2.7 \%$ (SEM; $n=6$ ) by somatostatin. Somatostatin did not appear to change the threshold for activation of the calcium current or the voltage of maximal current amplitude (Fig. $3 B$ ). Figure $3 D$ illustrates the time course of the effect of somatostatin on the calcium current. Application of somatostatin produced a significant decrease in the calcium current ( $p<0.0001$, unpaired $t$ test) as measured from 5 currents before somatostatin and 5 currents at the plateau of the somatostatin effect. This reduction of calcium current was reversible, as the current amplitude $100 \mathrm{sec}$ after the removal of somatostatin was not significantly different from the amplitude before somatostatin $(p>0.35)$. Figure $3 C$ shows the calcium current records for this experiment.

It seems likely that the reduction of calcium current produced by somatostatin accounts at least in part for the decrease in cytosolic calcium produced by the peptide. AtT-20 cells exhibit frequent spontaneous calcium action potentials, and influx of calcium through these channels appears to determine the cytosolic levels of this ion, as indicated by the effect of calcium channel blockers (Fig. 1). It cannot be excluded, however, that somatostatin might decrease cytosolic calcium by additional mechanisms. For instance, somatostatin could stimulate the active extrusion of calcium from the cytoplasm, or it might alter other membranc ion conductances, thercby polarizing the $\mathrm{mcm}$ brane to potentials where the activation of voltage-dependent calcium channels would be minimized or prevented. Further work is necessary to determine whether somatostatin also affects such mechanisms.

Richardson (1983) reported that somatostatin does not modify the rate of uptake of ${ }^{45} \mathrm{Ca}^{2+}$ in AtT-20 cells. The apparent discrepancy of this observation with our results could be due to the following: (1) In Richardson's experiments, the cells were preincubated for $20 \mathrm{~min}$ with somatostatin before testing uptake; (2) ${ }^{45} \mathrm{Ca}^{2+}$ uptake depends on the concentration gradient for calcium and the membrane potential of the cells; and (3) the uptake of radioactive calcium may reflect not only entry of this ion via voltage-dependent channels, but also ion-ion exchange processes, calcium binding to cell surfaces, and uptake into intracellular organelles. These factors may obscure an effect of somatostatin on calcium channels.

\section{Relationship to release}

One question pertinent to our results is whether the actions of somatostatin on calcium movements could play a role in the inhibition of ACTH release caused by the peptide. Somatostatin appears to inhibit secretagogue-stimulated release of $\mathrm{ACTH}$ by multiple mechanisms (Reisine, 1985). One well-defined effect of the peptide is the inhibition of cAMP synthesis induced by hormones such as CRF and norepinephrine (Axelrod and Reisine, 1984). Somatostatin also inhibits the action of secretagogues, such as 8-bromocyclic AMP and $\mathrm{K}^{+}$, which are independent of cAMP synthesis. Both of these secretagogues increase intracellular calcium; moreover, stimulation of ACTH release does not occur if extracellular calcium is not present. In addition, 8-bromocyclic AMP and $\mathrm{K}^{+}$appear to require the activity of voltage-dependent calcium channels, since their effects on ACTH release are suppressed by nifedipine and other calcium antagonists (A. Luini, unpublished observations). It is thus possible that the reduction of calcium current and/or cytosolic calcium

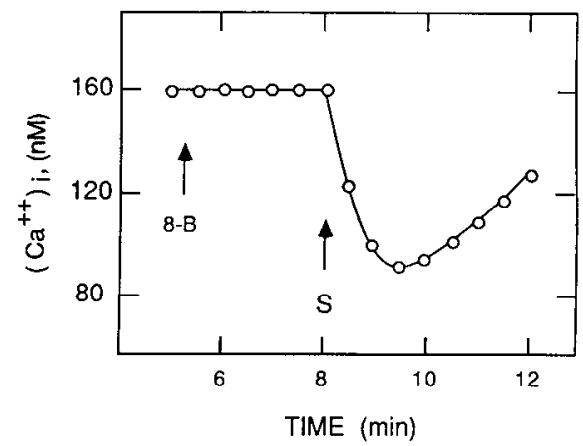

Figure 4. Effect of pretreatment with 8-bromocyclic AMP on the decrease in cytosolic calcium induced by somatostatin. Effect of $6 \mathrm{~mm}$ 8-bromocylic AMP ( $8-B$ ) followed by $10^{-7} \mathrm{M}$ somatostatin $(S)$ in cells exposed to $1 \mathrm{~mm} 8$-bromocylic AMP for $12 \mathrm{~min}$. 8-bromocyclic AMP increases cytosolic calcium in AtT-20 cells, as reported by Luini et al. (1985). The concentration and time of exposure to the nucleotide used in this experiment produce a maximal effect on cytosolic calcium levels. Values are means of 4-6 experiments carried out using 3 different preparations. SDs were less than $10 \%$ of the means.

caused by somatostatin might be a component of the mechanism by which this peptide inhibits release. An apparent difficulty with this hypothesis with respect to cytosolic calcium is that the effect of somatostatin on cytosolic calcium lasted 8-9 min, whereas the inhibition of ACTH release by somatostatin may last $60 \mathrm{~min}$ (I Ieisler et al., 1982). The short duration of the effects of somatostatin on cytosolic calcium levels does not appear to be due to degradation of the peptide, because a second addition of somatostatin after cytosolic calcium had returned to basal levels produced only a small effect (Fig. $1 A$ ). In addition, this phcnomcnon may not be due to desensitization, since basal calcium levels are also reestablished after treatment with nifedipine, a compound not known to desensitize. Our best explanation at present is that cytosolic calcium may return to control levels due to homeostatic mechanisms that would readjust the concentration of intracellular free $\mathrm{Ca}^{2+}$ in spite of continucd inhibition of calcium current, as occurs with nifedipine. Further work is needed to determine whether there is a desensitization of the effect of somatostatin on calcium channels.

\section{CAMP independence}

The somatostatin receptor in AtT-20 cells might be coupled to calcium channels via a second messenger such as cAMP. Since cAMP increases calcium current and cytosolic calcium levels in AtT-20 cells (Luini et al., 1985) and somatostatin is linked to the cyclase in an inhibitory fashion (Heisler et al., 1982), the effect of this peptide on calcium current and cytosolic calcium could be secondary to a decrease in cAMP concentration. We tested this possibility by 3 different experimental approaches. One was to examine the cAMP content in cells treated with somatostatin for $80 \mathrm{sec}$, a time sufficient to produce a nearly maximal decrease in cytosolic calcium (Fig. 1). Cells were loaded with Quin-2 and prepared as for a Quin-2 experient. The levels of cAMP in control and somatostatin-treated samples were not significantly different $\left(11.8 \pm 0.5\right.$ and $12.2 \pm 0.7 \mathrm{pmol} / 10^{6}$ cells, respectively). A second approach was to examine the effect of somatostatin in cells pretreated with the cAMP analog 8-bromocylic AMP. This compound, like cAMP, increases cytosolic calcium levels and the voltage-dependent calcium current in AtT -20 cells (Luini et al., 1985). If somatostatin reduces intracellular calcium by decreasing cAMP, then its effects on calcium should be abolished or reduced by a concentration of 8-bromocylic AMP that is supramaximal for increasing cytosolic calcium levels. In cells treated with $6 \mathrm{~mm} 8$-bromocyclic AMP (a concentration 5-fold in excess of that causing a maximal increase in cytosolic calcium; see Fig. 4), somatostatin still ex- 
erted a full effect on cytosolic calcium. A third approach to examining the role of cAMP in the inhibitory effect of somatostatin on calcium current was to perfuse the cell internally via the patch pipette with $100 \mu \mathrm{M}$ cAMP and $1 \mathrm{mM}$ of the phosphodiesterase inhibitor IBMX. This concentration of cAMP is 50- to 100-fold in excess of that found to saturate the cAMPdependent protein kinase from AtT-20 cells (Miyazaki et al., 1984). Under these conditions the effect of somatostatin (Fig. $3, E, F)$ appeared similar to the effect of somatostatin in cells recorded without cAMP and IBMX in the patch pipette (Fig. $3, C, D)$. These 3 lines of experimental evidence suggest that somatostatin exerts its effects on cytosolic calcium and calcium current independently of changes in cAMP concentration. Dorflinger and Schonbrunn (1983) have also reported cAMP-independent effects of somatostatin in $\mathrm{GH}_{3}$ pituitary cells.

It is possible that a second messenger other than cAMP might mediate the action of somatostatin on calcium channels. Alternatively, the somatostatin receptor could be coupled to calcium channels via one of the regulatory GTP binding proteins such as $\mathrm{G}_{i}$ or $\mathrm{G}_{\circ}$ (Sternweis and Robishaw, 1984). It has been reported (Heisler et al., 1982) that $\mathrm{G}_{\mathrm{i}}$ is linked to the receptor of somatostatin and mediates its inhibitory effect on cAMP synthesis. The G proteins, in addition to being regulatory components of the adenylate cyclase complex, have recently been shown to be involved in signal transduction systems controlling cytosolic calcium (Molski et al., 1984; Verghese et al., 1985).

\section{Conclusion}

Somatostatin reduces both the voltage-dependent calcium current and the concentration of intracellular free calcium ions in AIT-20 cells. These effects appear to be independent of the intracellular cAMP concentration. Inhibition of calcium channels and reduction of intracellular free calcium may be one of the mechanisms whereby somatostatin inhibits ACTH secretion in AtT-20 cells.

\section{References}

Adler, M., B. S. Wong, S. L. Sabol, N. Busis, M. B. Jackson, and F. F. Weight (1983) Action potentials and membrane ion channels in clonal pituitary cells. Proc. Natl. Acad. Sci. USA 80: 2086-2090.

Axelrod, J., and T. D. Reisine (1984) Stress hormones: Their interaction and regulation. Science 224: 452-459.

Boden, G., M. C. Sivitz, O. E. Owen, N. E. Essa-Koumar, and J. H. Landor (1975) Somatostatin suppresses secretin and pancreatic exocrine secretion. Science 190: 163-164.

Dorflinger, L. J., and A. Schonbrunn (1983) Somatostatin inhibits basal and vasuactive intestinal peptide-stimulated hormone release by different mechanisms in GH pituitary cells. Endocrinology 113: $1551-1558$.

Fujimoto, W. Y, J. W. Ensinck, and R. H. Williams (1974) Somatostatin inhibits insulin and glucagon release by monolayer cell cultures of rat endocrine pancreas. Life Sci. 15: 1999-2004.

Hamill, O. P., A. Marty, E. Neher, B. Sakmann, and F. J. Sigworth (1981) Improved patch-clamp technique for high-resolution current recording from cells and cell-free membrane patches. Pfluegers Arch. 391: $85-100$.

Heisler, S. (1984) 12-O-tetradecanoyl-phorbol-acetate-induced ACTH secretion in pituitary tumor cells. J. Pharmacol. 98: 177-183.

Heisler, S., T. D. Reisine, V. Y. H. Hook, and J. Axelrod (1982) Somatostatin inhibits multireceptor stimulation of cyclic AMP for- mation and corticotropin secretion in mouse pituitary tumor cells. Proc. Natl. Acad. Sci. USA 79: 6502-6506.

Hook, V. Y. H., S. Heisler, S. L. Sabol, and J. Axelrod (1982) Corticotropin releasing factor stimulates adrenocorticotropin and endorphin release from AtT-20 mouse pituitary tumor cells. Biochem. Biophys. Res. Commun. 106: 1364-1371

Luini, A., D. Lewis, S. Guild, D. Corda, and J. Axelrod (1985) Hormone secretagogues increase cytosolic calcium by increasing cAMP in corticotropin-secreting cells. Proc. Natl. $\Lambda$ cad. Sci. US $\Lambda$ 82: 8034 8038.

Maruyama, T., and H. Ishikawa (1977) Somatostatin: Its inhibiting effects on the release of hormones and IgG from clonal cell strains. Its Ca-influx dependence. Biochem. Biophys. Res. Commun. 74: 10831087.

Miyazaki, K., T. Reisine, and J. W. Kebabian (1984) Adenosine 3',5' monophosphate (cAMP)-dependent protein kinase activity in rodent pituitary tissue: Possible role in cAMP-dependent hormone secretion. Endrocrinology 115: 1933-1945.

Molski, T. F. P., P. H. Naccache, M. L. Marsh, J. Kermode, E. L. Becker, and R. I. Sha'afi (1984) Pertussis toxin inhibits the rise in the intracellular concentration of free calcium that is induced by chemotactic factors in rabbit neutrophils: Possible role of the $G$ proteins in calcium mobilization. Biochem. Biophys. Res. Commun. 124: 644650.

Oliver, J. R. (1976) Inhibition of calcium uptake by somatostatin in isolated rat islet of Langerhans. Endocrinology 99: 910-913.

Pace, C. J., and J. T. Tarvin (1981) Somatostatin: Mechanism of action in pancreatic islet $\beta$-cells. Diabetes $30: 836-842$.

Reichlin, S. (1984) Somatostatin. N. Engl. J. Med. 309: 1495-1499.

Reisine, T. (1984) Somatostatin desensitization: Loss of the ability of somatostatin to inhibit cAMP accumulation and adrenocorticotropin hormone release. J. Pharmacol. Exp. Ther. 229: 14-21.

Reisine, T. (1985) Multiple mechanisms of somatostatin inhibition of adrenocorticotropin release from mouse anterior pituitary tumor cells. Endocrinology 116: 2259-2266.

Richardson, V. I. (1983) Adrenocorticotropin secretion by mouse pituitary tumor cells in culture: The role of $\mathrm{Ca}^{2+}$ in stimulated and somatostatin-inhibited secretion. Endocrinology 113: 62-68.

Schlegel, W., F. Wuarin, C. B. Wollheim, and G. Zahnd (1984) Somatostatin lowers the cytosolic free calcium concentrations in clonal rat pituitary cells $\left(\mathrm{GH}_{3}\right.$ cells). Cell Calcium 5: 223-236.

Schlegel, W., F. Wuarin, C. Zbaren, and G. R. Zahnd (1985) Lowering of cytosolic free calcium by carbachol, a muscarinic cholinergic agent, in clonal pituitary cells ( $\mathrm{GH}_{3}$ cells). Endocrinology 117: 976-981.

Schofield, J. G., and R. J. Bicknell (1978) Effect of somatostatin and verapamil on growth hormone release and ${ }^{45} \mathrm{Ca}^{2+}$ fluxes. Mol. Cell. Endocrinol. 9: 255-268.

Sternweis, P. C., and I. D. Robishaw (1984) Isolation of two proteins with high affinity for guanine nucleotides from membranes of bovine brain. J. Biol. Chem. 259: 13806-13813.

Surprenant, A. (1982) Correlation between electrical activity and ACTH $/ \beta$-endorphin secretion in mouse pituitary tumor cells. J. Cell Biol. 95: 559-566.

Tsien, R. Y., T. Pozzan, and T. J. Rink (1982) Calcium homeostasis in intact lymphocytes: Cytoplasmic free calcium monitored with a new, intracellularly trapped fluorescent indicator. J. Cell Biol. 94: 325-334.

Vale, W., C. Rivier, and M. Brown (1977) Regulatory peptides of the hypothalamus. Annu. Rev. Physiol. 39: 473-527.

Verghese, M. W., C. D. Smith, and R. Snydermann (1985) Potential role for a guanine nucleotide regulatory protein in chemoattractant receptor mediated polyphosphoinositide metabolism, $\mathrm{Ca}^{2+}$ mobilization and cellular responses by leukocytes. Biochem. Biophys. Res. Commun. 127: 450-457. 